\title{
Neurocutaneous Melanosis in Infancy: Always a Dismal Prognosis?
}

\author{
Federico BIANCHI ${ }^{1}$, Gianpiero TAMBURRINI², Cesare COLOSIMO ${ }^{3}$, Luca MASSIMI², Paolo FRASSANITO' \\ ${ }^{1}$ Fondazione Policlinico Gemelli IRCSS, Department of Pediatric Neurosurgery, Rome, Italy \\ ${ }^{2}$ Università Cattolica del Sacro Cuore, Institute of Neurosurgery, Rome, Italy \\ ${ }^{3}$ Università Cattolica del Sacro Cuore, Institute of Radiology, Rome, Italy
}

Corresponding author: Federico BIANCHI fede0786@hotmail.it

\section{ABSTRACT}

AIM: To analyze the current literature on neurocutaneous melanosis (NCM), as well as, our cases, in order to better define the prognosis and the presence of risk factors affecting it, thus, offering better information to the parents.

MATERIAL and METHODS: Two cases observed at the Pediatric Neurosurgery Unit of the Catholic University Medical School in Rome are described. Both of them had cutaneous stigmata and cerebral MR evidence of intracranial melanin deposits. These two children showed a very different clinical course.

RESULTS: The present study enlighten the differences among the two cases and review the literature on the subject, with the attempt to understand which are clinical and disease related factors that might influence the prognosis.

CONCLUSION: Beside malignant features of cutaneous melanotic lesions, the presence of hydrocephalus at diagnosis and the early appearance of clinical symptoms, when appearing contemporarily, are predicting the rapid progression of the disease and a worse prognosis.

KEYWORDS: Neurocutaneus melanosis, Hydrocephalus, Personalized medicine

\section{INTRODUCTION}

$\mathrm{N}$ eurocutaneous melanosis (NCM) is a complex disease, commonly included among phacomatoses. It affects the integument, central nervous system and vascular system, and less commonly the splanchnic organs. Rokitansky, in 1861, described for the first time a new pathological condition characterized by the presence of large or multiple cutaneous nevi and brain parenchymal as well as leptomeningeal melanocytosis. The syndrome was subsequently reported and named by Van Bogaert in 1948. Its diagnostic criteria include large or multiple ( $\geq$ three) congenital cutaneous nevi, evidence of meningeal deposits of melanin (MR/histology) and no evidence of cutaneous or meningeal melanoma. The definition of large cutaneous nevi differs according to the patient's age and nevi site: a diameter $20 \mathrm{~cm}$ or larger refers to adolescents and adults, whereas a diameter of nine $\mathrm{cm}$ for the scalp and of six $\mathrm{cm}$ or larger on the body are size limits for an infant. Nevi distribution typically involves the head, neck, and trunk, or is in the shape of an old-fashioned bathing suit (covering the lower abdomen, pelvis, buttocks, and upper thighs) $(11,41)$.

Symptomatic patients might present very variably with seizures, signs and symptoms of intracranial hypertension and/or focal neurological deficits according to the main intracranial location of the disease and presence or absence of association with a mass effect (15).

Diagnostic workout starts with careful dermatological examination with particular care in depicting malignant cutaneous manifestations. Brain MR is indicated in all cases to show the
Federico BIANCHI

(D) : 0000-0002-8216-8581

Gianpiero TAMBURRINI (D) : 0000-0002-7139-5711

Cesare COLOSIMO
(1) : $0000-0003-3800-3648$
Luca MASSIMI (1): 0000-0003-3088-0822

Paolo FRASSANITO (1) : 0000-0003-0071-3126 
presence of melanin deposits, focal solid or cystic melanocytic lesions and to document the presence of CSF disturbances.

Many uncertainties remain about the pathogenesis and prognosis of NCM.

Since its first description, 135 cases have been reported, but no clear prognostic features or predictors for outcome have been identified. However, contrary to the common belief that $\mathrm{NCM}$ has very bad prognosis, several cases of long-term survivors have been reported.

In this paper, we will analyze the current literature on NCM, as well as, our cases, in order to better define the prognosis and the presence of risk factors affecting it, thus, offering better information to the parents.

\section{MATERIAL and METHODS}

Two pediatric cases observed at the Pediatric Neurosurgery Unit of the Catholic University Medical School, Rome, Italy, have been retrospectively reviewed. The two children showed extremely different prognosis. Along with the description of the cases, a review of the literature has been conducted to definebased on both personal findings and literature review-clinical factors that might help in the prediction of the prognosis of the children.

\section{Exemplary Case Description}

Case 1

K.J. is a neurologically intact two-month-old boy with evidence at birth of multiple small nevi of the head and trunk with the tendency in time to grow in number and volume (Figure 1). A screening MR scan showed the presence of a posterior fossa arachnoid cyst associated with melanin deposit in the cerebellar folia. There was no radiological evidence of hydrocephalus or solid masses (Figure 2). A microsurgical biopsy of the cerebellar cortex was performed and the histological sample was compatible with BRAF negative melanin deposit. Biopsy was performed in the neurologically intact patient in order to understand beforehand, whether there were possibilities for BRAF-related chemotherapy. At three years follow-up, the baby is in good clinical condition without neurological deficits or evidence of disease progression. Control MR Scans show reduction in volume and number of cerebellar melanin deposits

\section{Case 2}

A.C. is a three-year-old girl with evidence at birth of multiple big nevi in the lower trunk (Figure 3). Due to the evidence of delay in psychomotor development, reduction in visual acuity with poor light reflex and myoclonic response in the lower

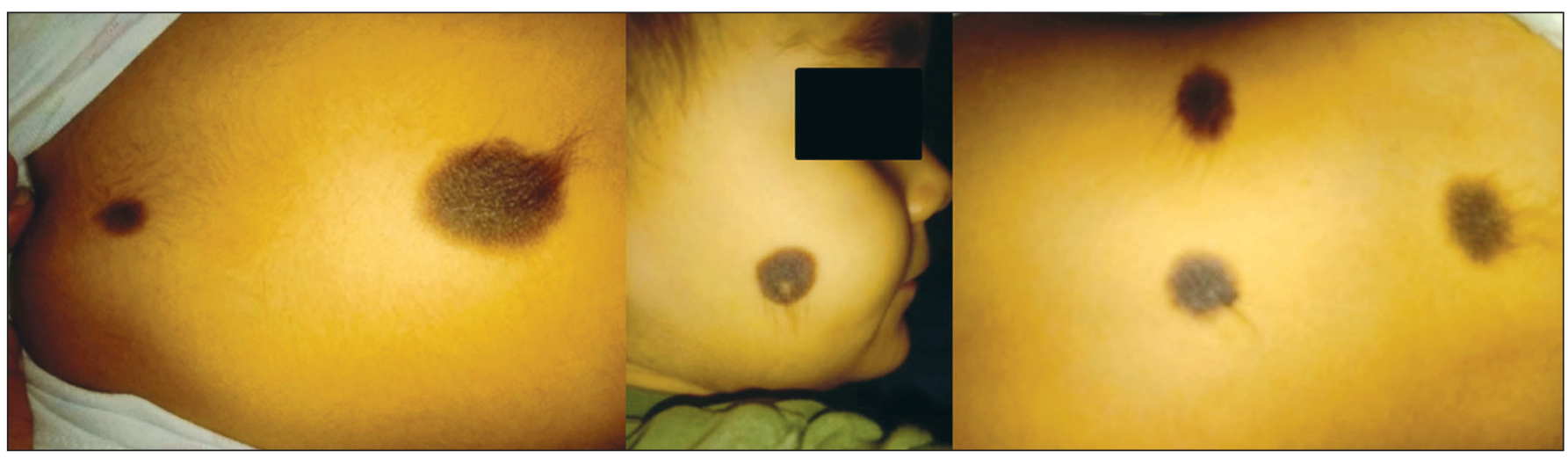

Figure 1: Case 1 cutaneous manifestation.

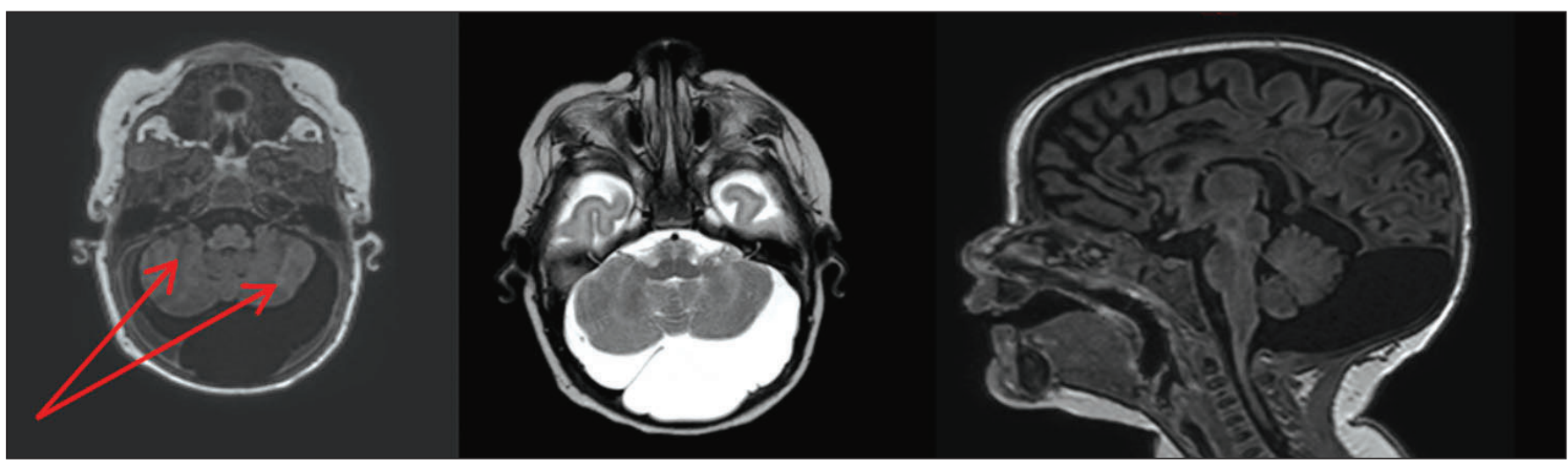

Figure 2: Patient 1: MRI scan showing melanin deposits and a posterior fossa cyst in Axial T1, Axial T2 and Sagittal T1. No hydrocephalus is documented. 
limbs, an MRI scan was performed at eight months of age showing the presence of cerebellar hypoplasia associated with melanin deposit in the cerebellar folia (Figure 4). At the age of one, the child started to present tonic-clonic seizures particularly involving the right side with poor response to medical treatment, which contributed to worsening of cognitive conditions. A new MRI showed the development of a large arachnoid cyst in the posterior cranial fossa, left frontoparietal meningeal lesion and bilateral subdural hematoma. Microsurgical biopsy of the frontal lesion and meningeal plane was performed with histology compatible with NCM. The patient was then operated to evacuate subdural collections. After an initial improvement in the clinical conditions, we assisted with a rapid deterioration of the neurological status, which ended with the exitus of the child at 16 months of age.

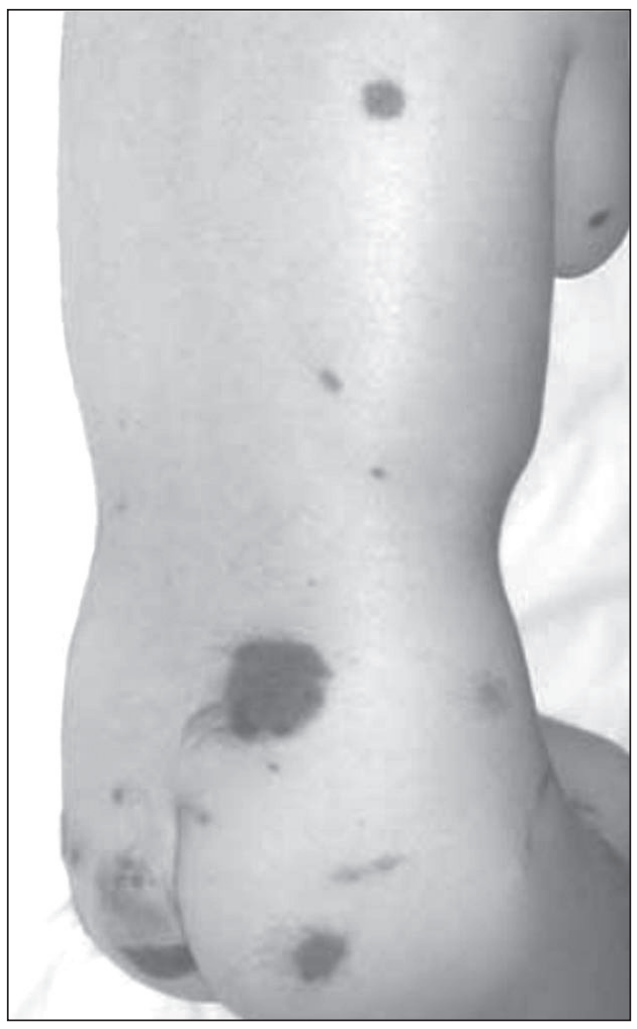

Figure 3: Case 2 cutaneous manifestation.

\section{REVIEW}

A thorough review of the literature revealed 54 papers that have reported on clinical cases (Table I). Most of them are case reports or small case series with a total of 269 patients. None of them discuss factors that might influence the prognosis. The majority of the papers describe pediatric patients (1$3,5-10,12-15,17-29,31-38,40-49,51-53)$; while only five are centered on adults $(16,25,30,50,54)$. The typical cutaneous aspects of NCM were described in all cases. Hydrocephalus development or malignant transformation was described in 52 patients.

An extreme variation in the prognosis is evident from the description of patients who died before delivery, as well as, patients who were alive 12-18 years after the diagnosis $(18,36,45,47)$.

We performed a statistical analysis of the data reported in the literature and added to it our two cases. The Chi square test was performed, either for single variables or in multivariate fashion. Confidence interval was fixed at five percent. From the multivariate analysis, the most prominent result was that the association between infantile age, malignant transformation of cutaneous nevi and early development of hydrocephalus $(p=0.0126$ trunk nevi, $p=0.0132$ diffuse nevi) is associated with the worse prognosis.

\section{DISCUSSION}

NCM is known as a disease characterized by bad prognosis, if diagnosed in the first year of life. Non-negligible proportion of infants and children has been described with long-term survival and no information is present in the literature regarding which might be the positive or negative factors that influence the prognosis of the children.

The association between hydrocephalus and malignant malformation of the nevi as well as the isolated malignant transformation of the cutaneous lesions negatively influence the course of the disease. In fact, three/four children with both the development of malignant cutaneous lesions, as well as hydrocephalus at diagnosis, died at a mean follow-up of 210 months. Similarly, six or seven children with selective cutaneous malignant transformation died (mean follow-up 14 months). The presence of hydrocephalus alone, without

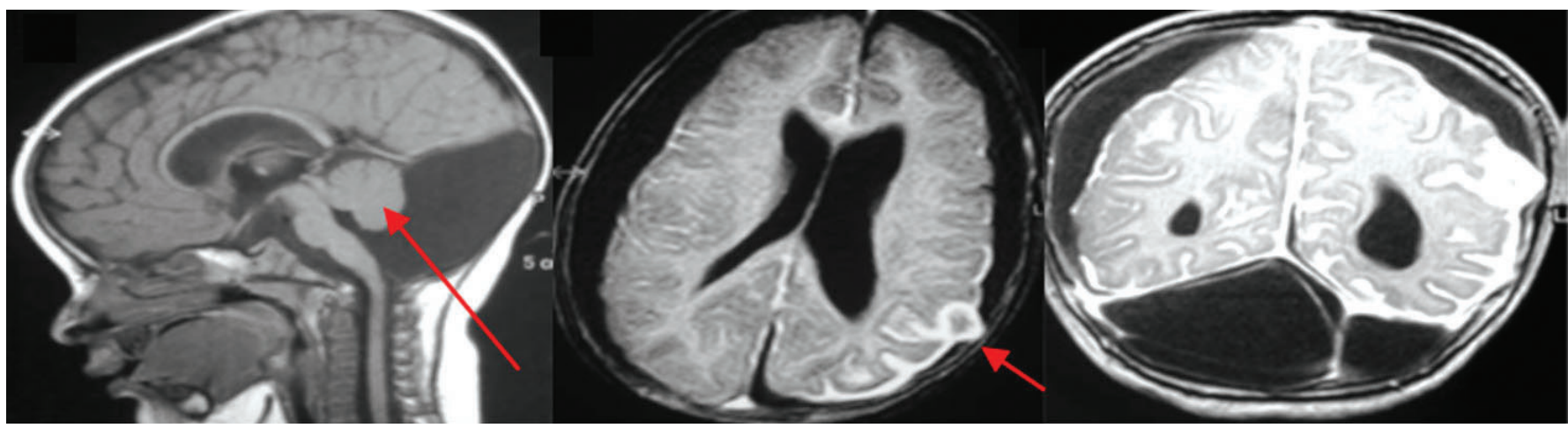

Figure 4: Patient 2: MRI scan showing melanin deposits and a posterior fossa cyst in Sagittal T1, Axial T1 with contrast and Coronal T1 with contrast. 
Table I: Review of the Literature

\begin{tabular}{|c|c|c|c|c|c|c|}
\hline Paper & $\begin{array}{c}\text { Number } \\
\text { of } \\
\text { Patients }\end{array}$ & $\begin{array}{l}\text { Age (Years/ } \\
\text { months) }\end{array}$ & $\begin{array}{c}\text { Mole } \\
\text { Location }\end{array}$ & $\begin{array}{c}\text { Malignant } \\
\text { Transformation } \\
\text { (Y/N) }\end{array}$ & $\begin{array}{l}\text { Hydrocephalus } \\
\text { (Y/N) }\end{array}$ & $\begin{array}{l}\text { Follow-up from } \\
\text { Symptoms Appearance }\end{array}$ \\
\hline Sharouf et al. (41), 2018 & 1 & 5 months & Trunk & $\mathrm{N}$ & $\mathrm{Y}$ & Dead after 17 months \\
\hline Liao et al. (28), 2017 & 1 & 9 years & & $\mathrm{Y}$ & $\mathrm{N}$ & Dead after 3 months \\
\hline Chen et al. (9), 2016 & 1 & Newborn & Trunk & $\mathrm{N}$ & $\mathrm{N}$ & Alive after 3 months \\
\hline Gocmen et al. (18), 2015 & 1 & Newborn & Trunk & $\mathrm{N}$ & $\mathrm{Y}$ & Alive after 18 years \\
\hline Siddiqui et al. (43), 2015 & 1 & 5 years & Trunk & $\mathrm{Y}$ & $\mathrm{N}$ & Dead after 8 months \\
\hline \multirow{2}{*}{ Uguen et al. (48), 2015} & \multirow{2}{*}{2} & Newborn & Trunk & $\mathrm{N}$ & $\mathrm{Y}$ & Dead before birth \\
\hline & & Newborn & Trunk & $\mathrm{N}$ & $\mathrm{Y}$ & Dead before birth \\
\hline Guerra-Garcia et al. (20), 2014 & 1 & Newborn & Trunk & $\mathrm{N}$ & $\mathrm{N}$ & Alive after 3 years \\
\hline Shih et al. (42), 2014 & 1 & 2 months & Diffuse & $\mathrm{Y}$ & $\mathrm{N}$ & Alive after 2 years \\
\hline Yoo et al. (53), 2014 & 1 & 4 months & Diffuse & $\mathrm{Y}$ & $\mathrm{Y}$ & Dead after 2 years \\
\hline Jain et al. (22), 2013 & 1 & 3 years & Trunk & $\mathrm{Y}$ & $\mathrm{N}$ & - \\
\hline Taylor et al. (47), 2013 & 1 & 4 months & Trunk & $\mathrm{N}$ & $\mathrm{N}$ & Alive after 16 years \\
\hline Yamazaki et al. (52), 2013 & 1 & 9 years & Trunk & $\mathrm{N}$ & $\mathrm{Y}$ & Dead after 11 months \\
\hline Furtado et al. (17), 2012 & 1 & 13 years & Diffuse & $\mathrm{Y}$ & $\mathrm{N}$ & Dead after 6 months \\
\hline Kim et al. (26), 2012 & 1 & 8 years & Trunk & $\mathrm{N}$ & $\mathrm{N}$ & Alive after 1 year \\
\hline Dechaphunkul et al. (14), 2011 & 1 & 17 years & - & $\mathrm{N}$ & $\mathrm{N}$ & Alive after 2 years \\
\hline $\begin{array}{l}\text { Taboada-Suarez et al. (47), } \\
2011\end{array}$ & 1 & 3 years & Trunk & $\mathrm{N}$ & $\mathrm{N}$ & Alive after 12 years \\
\hline Subbiah and Wolff (44), 2010 & 1 & 9 months & - & $\mathrm{Y}$ & $\mathrm{Y}$ & Alive after 5 years \\
\hline Livingstone et al. (29), 2009 & 1 & Infant & Trunk & $\mathrm{Y}$ & $\mathrm{Y}$ & Dead after 1 year \\
\hline Marnet et al. (31), 2009 & 1 & 14 years & Trunk & $\mathrm{Y}$ & $\mathrm{Y}$ & Dead after 1 year \\
\hline \multirow{2}{*}{ Cajaiba et al. (8), 2008} & 1 & 7 years & Trunk & $\mathrm{Y}$ & $\mathrm{Y}$ & Dead after 2 weeks \\
\hline & 1 & 3 years & Diffuse & $\mathrm{Y}$ & $\mathrm{Y}$ & Dead after 2 years \\
\hline \multirow{3}{*}{ Pavlidou et al. (36), 2008} & \multirow{3}{*}{3} & Newborn & Diffuse & $\mathrm{N}$ & $\mathrm{N}$ & Alive after 16 years \\
\hline & & Newborn & Trunk & $\mathrm{N}$ & $\mathrm{N}$ & Alive after 9 years \\
\hline & & 6 years & Diffuse & $\mathrm{N}$ & $\mathrm{Y}$ & Dead after 7 years \\
\hline \multirow{14}{*}{ Schreml et al. (40), 2008} & \multirow{14}{*}{14} & 16 years & Diffuse & $\mathrm{N}$ & $\mathrm{Y}$ & Dead after few days \\
\hline & & 3 months & Diffuse & $\mathrm{N}$ & $\mathrm{Y}$ & Dead after 1 year \\
\hline & & 28 days & Diffuse & $\mathrm{N}$ & $\mathrm{Y}$ & Alive \\
\hline & & 4 months & Diffuse & $\mathrm{N}$ & $\mathrm{Y}$ & Dead after 4 years \\
\hline & & 6 weeks & Diffuse & $\mathrm{N}$ & $\mathrm{Y}$ & Dead after 2 years \\
\hline & & Newborn & Diffuse & $\mathrm{N}$ & $\mathrm{Y}$ & Dead after 18 months \\
\hline & & 1 month & Diffuse & $\mathrm{N}$ & $\mathrm{Y}$ & Alive \\
\hline & & Newborn & Diffuse & $\mathrm{N}$ & $\mathrm{Y}$ & Alive \\
\hline & & 18 weeks & Diffuse & $\mathrm{N}$ & $\mathrm{Y}$ & Alive \\
\hline & & 2 months & Diffuse & $\mathrm{N}$ & $\mathrm{Y}$ & Dead after 5 years \\
\hline & & 5 years & Diffuse & $\mathrm{N}$ & $\mathrm{Y}$ & Alive \\
\hline & & 4 months & Diffuse & $\mathrm{N}$ & $\mathrm{Y}$ & Alive \\
\hline & & 4 months & Diffuse & $\mathrm{N}$ & $\mathrm{Y}$ & Alive \\
\hline & & 6 years & Diffuse & $\mathrm{N}$ & $\mathrm{Y}$ & Alive \\
\hline
\end{tabular}


Table I: Cont.

\begin{tabular}{|c|c|c|c|c|c|c|}
\hline Paper & $\begin{array}{c}\text { Number } \\
\text { of } \\
\text { Patients }\end{array}$ & $\begin{array}{l}\text { Age (Years/ } \\
\text { months) }\end{array}$ & $\begin{array}{c}\text { Mole } \\
\text { Location }\end{array}$ & $\begin{array}{c}\text { Malignant } \\
\text { Transformation } \\
\text { (Y/N) }\end{array}$ & $\begin{array}{l}\text { Hydrocephalus } \\
\text { (Y/N) }\end{array}$ & $\begin{array}{l}\text { Follow-up from } \\
\text { Symptoms Appearance }\end{array}$ \\
\hline D’Argenio et al. (12), 2007 & 1 & Newborn & Trunk & $\mathrm{N}$ & $\mathrm{N}$ & Alive after 1 year \\
\hline McClelland et al. (32), 2007 & 1 & 1 year & Diffuse & $\mathrm{N}$ & Y & Dead after 2 weeks \\
\hline Kalayci et al. (24), 2006 & 1 & Newborn & Trunk & $\mathrm{N}$ & $\mathrm{Y}$ & Dead after 6 months \\
\hline Iwabuchi et al. (21), 2005 & 1 & Newborn & Diffuse & $\mathrm{N}$ & $\mathrm{Y}$ & Alive after 1 year \\
\hline Miranda et al. (34), 2005 & 1 & 10 years & Head & $\mathrm{Y}$ & $\mathrm{N}$ & Dead after 2 weeks \\
\hline Berker et al. (6), 2000 & 1 & 2 years & $\begin{array}{l}\text { Trunk and } \\
\text { head }\end{array}$ & $\mathrm{Y}$ & $\mathrm{N}$ & Dead after 2 years \\
\hline Peters et al. (37), 2000 & 1 & 3 weeks & Trunk & $\mathrm{N}$ & $\mathrm{Y}$ & Alive after 8 years \\
\hline Vanzieleghem et al. (49), 1999 & 1 & 14 months & Trunk & $\mathrm{N}$ & $\mathrm{Y}$ & Dead after 9 months \\
\hline Lamas et al. (27), 1977 & 1 & 15 years & Diffuse & $\mathrm{Y}$ & $\mathrm{N}$ & Dead after 6 months \\
\hline \multirow{2}{*}{ Present cases } & 1 & 2 months & Trunk & $\mathrm{N}$ & $\mathrm{N}$ & Alive after 18 months \\
\hline & 1 & 3 years & Trunk & Y & $\mathrm{N}$ & Dead after 6 months \\
\hline
\end{tabular}

Y: Yes, N: No.

malignant cutaneous transformation on the other hand did not seem to impact the prognosis of the children, whereas the absence of both melanocytic malignancy and hydrocephalus positively influenced the prognosis: all eight children in the group were alive at the mean follow-up of 84 months.

The trend is confirmed by our exemplary cases. The first child (Case 1) with no signs of hydrocephalus or malignant cutaneous transformation is in stable and good neurological conditions, now at a follow-up of three years. MRI controls show a reduction in the amount of melanin deposit-an aspect previously described in children with NCM and good prognosis (4). On the other hand, case 2 who developed hydrocephalus shortly after the diagnosis, though had similar melanocytic involvement of the meninges, died eight months after diagnosis.

Unifying our data with that from the literature, the presence of hydrocephalus seems to be a much more important risk factor than what has been considered in the past. CSF dynamic impairment and malignant cell migration look to act contemporarily in leading to an early appearance of symptoms and higher aggressiveness of the disease, finally predicting worse prognosis.

The considerations might help the physician in depicting the most probable scenario in differently presenting the conditions. NCM most probably represents a group of different diseases also in infancy. Immunohistochemistry analysis of the meningeal melanocytes has not shown differences between children with more aggressive disease progression, compared to those with a more favorable prognosis.

Molecular analysis and genetic profiling might help in defining the issue; however, even from this point of view, though several mutations have been identified, the majority involve the NRAS and BRAF genes, and none of them has been associated to worse prognosis (39).

\section{CONCLUSION}

NCM is a phacomatosis typically seen in infants and toddlers with a wide spectrum of clinical presentation and prognosis. Presence of hydrocephalus and consequent early clinical symptoms are indicative of disease progression and worse prognosis. Molecular studies are needed to better evaluate the condition to have additional factors that might predict the prognosis.

\section{REFERENCES}

1. Acosta FL, Binder DK, Barkovich AJ, Frieden IJ, Gupta N: Neurocutaneous melanosis presenting with hydrocephalus. Case report and review of the literature. J Neurosurg 102 Suppl 1:96-100, 2005 
2. Arai M, Nosaka K, Kashihara K, Kaizaki Y: Neurocutaneous melanosis associated with Dandy-Walker malformation and a meningohydroencephalocele. Case report. J Neurosurg 100 Suppl Pediatrics 5:501-505, 2004

3. Asano T, Hamada H, Takita Y, Watanabe M, Sugano H, Sudoh M, Yamanishi M, Kuwabara K, Imai T, Fujino O: Neurocutaneous melanosis with acute disseminated encephalomyelitis. Eur J Pediatr 166(10):1065-1066, 2007

4. Bekiesinska-Figatowska M, Sawicka E, Zak K, Szczygielski $\mathrm{O}$ : Age related changes in brain MR appearance in the course of neurocutaneous melanosis. Eur J Radiol 85(8):1427-1431, 2016

5. Bekiesinska-Figatowska M, Szczygielski O, Boczar M, Madzik J, Klepacka T, Michalak E, Romaniuk-Doroszewska A, Uliasz M, Peczkowski P, Sawicka E: Neurocutaneous melanosis in children with giant congenital melanocytic nevi. Clin Imaging 38(2):79-84, 2014

6. Berker M, Oruckaptan HH, Oge HK, Benli K: Neurocutaneous melanosis associated with Dandy-Walker malformation. case report and review of the literature. Pediatr Neurosurg 33(5): 270-273, 2000

7. Caceres A, Trejos $\mathrm{H}$ : Neurocutaneous melanosis with associated Dandy-Walker complex. Childs Nerv Syst 22(1):6772, 2006

8. Cajaiba MM, Benjamin D, Halaban R, Reyes-Mugica M: Metastatic peritoneal neurocutaneous melanocytosis. Am J Surg Pathol 32(1):156-161, 2008

9. Chen YA, Woodley-Cook J, Sgro M, Bharatha A: Sonographic and magnetic resonance imaging findings of neurocutaneous melanosis. Radiol Case Rep 11(1):29-32, 2016

10. Chu WCW, Lee V, Chan Y, Shing MMK, Chik K, Li C, Ma K: Neurocutaneous melanomatosis with a rapidly deteriorating course. AJNR Am J Neuroradiol 24(2):287-290, 2003

11. Danial-Mamlouk C, Mamlouk MD, Handwerker J, Hasso AN: Case 220: Neurocutaneous melanosis. Radiology 276(2): 609613, 2015

12. D'Argenio A, David P, Engohan C, Hennequin Y, Baleriaux $D$, Jissendi $P$ : Neurocutaneous melanosis in a newborn with giant congenital melanocytic nevus. J Neuroradiol 34(4):272275,2007

13. De Cock J, Snauwaert J, Van Rompaey W, Morren M-A, Demaerel P: A newborn with neurocutaneous melanocytosis and Dandy-Walker malformation. Pediatr Neurol 50(3):276278, 2014

14. Dechaphunkul A, Kayasut K, Oearsakul T, Koonlaboon K, Sunpaweravong $\mathrm{P}$ : Common presentation in an uncommon disease: Case report of a patient with primary diffuse leptomeningeal melanocytosis. J Clin Oncol 29(33):e816-818, 2011

15. Di Rocco F, Sabatino G, Koutzoglou M, Battaglia D, Caldarelli M, Tamburrini G: Neurocutaneous melanosis. Childs Nerv Syst 20(1):23-28, 2004

16. Faillace WJ, Okawara SH, McDonald JV: Neurocutaneous melanosis with extensive intracerebral and spinal cord involvement. Report of two cases. J Neurosurg 61(4):782-785, 1984
17. Furtado S, Furtado SV, Ghosal N, Hegde AS: Fatal leptomeningeal melanoma in neurocutaneous melanosis. Pediatr Dermatol 29(3):358-361, 2012

18. Gocmen R, Guler E, Arslan EA: A case of neurocutaneous melanosis and neuroimaging findings. J Radiol Case Rep 9(3): 1-6, 2015

19. Green LJ, Nanda VS, Roth GM, Barr RJ: Neurocutaneous melanosis and Dandy-Walker syndrome in an infant. Int $\mathrm{J}$ Dermatol 36(5):356-359, 1997

20. Guerra-Garcia P, Martinez-de-Aragon A, Camacho A: Neurocutaneous melanosis: An illustrative patient. Pediatr Neurol 51(3):468-469, 2014

21. Iwabuchi T, Shimotake T, Furukawa T, Tsuda T, Aoi S, Iwai N: Neurocutaneous melanosis associated with Hirschsprung's disease in a male neonate. J Pediatr Surg 40(8): E11-13, 2005

22. Jain P, Kannan L, Kumar A, Sigamani E, Suri V, Basheer N, Suri A, Gulati S: Symptomatic neurocutaneous melanosis in a child. JAMA Neurol 70(4):516, 2013

23. Johnson JM, Patten LL, Robson CD, Teele RL: Ultrasonographic detection of intracranial melanocytosis in an infant. Pediatr Radiol 40(2):210-214, 2010

24. Kalayci M, Cagavi F, Bayar U, Gul S, Dursun A, Ermis B, Acikgoz B: Neurocutaneous melanosis associated with Dandy-Walker malformation. Acta Neurochir (Wien) 148(10): 1103-1106; discussion 1106, 2006

25. Kang SG, Yoo DS, Cho KS, Kim DS, Chang ED, Huh PW, Kim MC: Coexisting intracranial meningeal melanocytoma, dermoid tumor, and Dandy-Walker cyst in a patient with neurocutaneous melanosis. Case report. J Neurosurg 104(3): 444-447, 2006

26. Kim KH, Chung SB, Kong DS, Seol HJ, Shin HJ: Neurocutaneous melanosis associated with Dandy-Walker complex and an intracranial cavernous angioma. Childs Nerv Syst 28(2):309-314, 2012

27. Lamas E, Diez Lobato R, Sotelo T, Ricoy JR, Castro S: Neurocutaneous melanosis. Report of a case and review of the literature. Acta Neurochir (Wien) 36(1-2):93-105, 1977

28. Liao K, Que S, Qiu Y, Zhang S, Chen Z: Neurocutaneous melanosis presenting as cavernous hemangioma persistent abdominal pain. J Craniofac Surg 28(2):e168-170, 2017

29. Livingstone E, Claviez A, Spengler D, Barth H, Stark AM, Hugo $\mathrm{HH}$, Hauschild A: Neurocutaneous melanosis: A fatal disease in early childhood. J Clin Oncol 27(13): 2290-2291, 2009

30. Ma M, Ding ZL, Cheng ZQ, Wu G, Tang XY, Deng P, Wu JD: Neurocutaneous melanosis in an adult patient with intracranial primary malignant melanoma: Case report and review of the literature. World Neurosurg 114:76-83, 2018

31. Marnet D, Vinchon M, Mostofi K, Catteau B, Kerdraon O, Dhellemmes P: Neurocutaneous melanosis and the DandyWalker complex: An uncommon but not so insignificant association. Childs Nerv Syst 25(12):1533-1539, 2009

32. McClelland S, Charnas LR, SantaCruz KS, Garner HP, Lam $\mathrm{CH}$ : Progressive brainstem compression in an infant with neurocutaneous melanosis and Dandy-Walker complex following ventriculoperitoneal shunt placement for hydrocephalus. Case report. J Neurosurg 107 Suppl 6:500503, 2007 
33. Mena-Cedillos CA, Valencia-Herrera AM, Arroyo-Pineda Al, Salgado-Jiménez MA, Espinoza-Montero R, MartínezAvalos AB, Perales-Arroyo A: Neurocutaneous melanosis in association with the Dandy-Walker complex, complicated by melanoma: Report of a case and literature review. Pediatr Dermatol 19(3):237-242, 2002

34. Miranda P, Esparza J, Hinojosa J, Munoz A: Neurocutaneous melanosis and congenital melanocytic nevus in the head. Pediatr Neurosurg 41(2):109-111, 2005

35. Monica I, Kumar LP, Uppin MS, Jagannath Rao Naidu KV: Neurocutaneous melanocytosis presenting in a teenager: $A$ case report and review of the literature. J Cancer Res Ther 11(3):649, 2015

36. Pavlidou E, Hagel C, Papavasilliou A, Giouroukos S, Panteliadis C: Neurocutaneous melanosis: Report of three cases and upto-date review. J Child Neurol 23(12):1382-1391, 2008

37. Peters R, Jansen G, Engelbrecht V: Neurocutaneous melanosis with hydrocephalus, intraspinal arachnoid collections and syringomyelia: Case report and literature review. Pediatr Radiol 30(4):284-288, 2000

38. Queiroz RM, Lauar LZ, Valentin MVN, Miyake $\mathrm{CH}$, Abud LG: Immune reconstitution inflammatory syndrome, with pulmonary and neurological cryptococcosis, in an HIVnegative patient. Radiol Bras 49(6):411-412, 2016

39. Ruggieri M, Pratico AD: Mosaic neurocutaneous disorders and their causes. Semin Pediatr Neurol 22(4):207-233, 2015

40. Schreml S, Gruendobler B, Schreml J, Bayer M, Ladoyanni E, Prantl L, Eichelberg G: Neurocutaneous melanosis in association with Dandy-Walker malformation: Case report and literature review. Clin Exp Dermatol 33(5):611-614, 2008

41. Sharouf F, Zaben M, Lammie A, Leach P, Bhatti MI: Neurocutaneous melanosis presenting with hydrocephalus and malignant transformation: Case-based update. Childs Nerv Syst 34(8):1471-1477, 2018

42. Shih F, Yip S, McDonald PJ, Chudley AE, Del Bigio MR: Oncogenic codon 13 NRAS mutation in a primary mesenchymal brain neoplasm and nevus of a child with neurocutaneous melanosis. Acta Neuropathol Commun 2: 140, 2014

43. Siddiqui MA, Siddiqui S, Zaman N, Ahmad I, Ullah E: Neurocutaneous melanosis: Review of a rare non-familial neuroectodermal dysplasia with newer association of cerebellopontine angle cistern lipoma. Neuroradiol J 28(2): 222-226, 2015
44. Subbiah V, Wolff JEA: Rapid response to therapy of neurocutaneous melanosis with leptomeningeal melanoma. Pediatr Blood Cancer 54(1):180-181, 2010

45. Taboada-Suarez A, Brea-Garcia B, Suarez-Penaranda JM, Couto-Gonzalez I: Neurocutaneous melanosis in association with proliferative skin nodules. Pediatr Dermatol 28(6):681684, 2011

46. Takano T, Morimoto M, Sakaue Y, Takeuchi Y, Aotani H, Ohno M: Large congenital melanocytic nevi presenting with lissencephaly with an absent corpus callosum. Congenit Anom 48(2):97-100, 2008

47. Taylor DR, Wait SD, Wheless JW, Boop FA: Amygdalar neuromelanosis intractable epilepsy without leptomeningeal involvement. J Neurosurg Pediatr 12(1):21-24, 2013

48. Uguen A, Laurent C, Samaison L, Boisselier B, Talagas M, Costa S, Aziza J, Mokhtari K, Le Marechal C, Marcorelles P: Severe hydrocephalus caused by diffuse leptomeningeal and neurocutaneous melanocytosis of antenatal onset: a clinical, pathologic, and molecular study of 2 cases. Hum Pathol 46(8):1189-1196, 2015

49. Vanzieleghem BD, Lemmerling MM, Van Coster RN: Neurocutaneous melanosis presenting with intracranial amelanotic melanoma. AJNR Am J Neuroradiol 20(3):457460, 1999

50. Walbert T, Sloan AE, Cohen ML, Koubeissi MZ: Symptomatic neurocutaneous melanosis and Dandy-Walker malformation in an adult. J Clin Oncol 27(17):2886-2887, 2009

51. Wen WH, Lee WT, Lin MI, Lin HC, Chiu HC, Shen YZ: Neurocutaneous melanosis with epilepsy: Report of one case. Taiwan Er Ke Yi Xue Hui Za Zhi 42(2):108-110, 2001

52. Yamazaki Y, Matsuzawa T, Takasugi K, Suzuki N, Kanda M, Kobayashi I: Rapidly progressive and fatal neurocutaneous melanosis presenting as recurrent headache. Pediatr Int 55(2):240-243, 2013

53. Yoo IH, Yum SK, Oh SJ, Kim KM, Jeong DC: Melanotic neuroectodermal tumor of infancy disseminated by a ventriculoperitoneal shunt and diagnosed from the inguinal sac. J Pediatr Hematol Oncol 36(1):e61-64, 2014

54. Zhang W, Miao J, Li Q, Liu R, Li Z: Neurocutaneous melanosis in an adult patient with diffuse leptomeningeal melanosis and a rapidly deteriorating course: Case report and review of the literature. Clin Neurol Neurosurg 110(6):609-613, 2008 